\title{
Global Governance with Chinese Char- acteristics? A Preliminary Analysis
}

\author{
GERALD CHAN
}

\begin{abstract}
The rise of China poses many challenges and opportunities for China as well as for other countries. Will its rapid rise in power change the way in which world affairs are run? If so, in what way will global governance be affected? What are China's aspirations, demands and limitations in its engagement with global governance? This paper addresses these questions. First, it takes a look at China's view of the nature of global governance. Then it identifies the principles and tactics used by the Chinese government in dealing with global governance before making an assessment of the special features of Chinese international relations in this area. Next the paper turns to the perceptions of other major countries towards China's behaviour in the area. It concludes by suggesting that China's increasing involvement in global governance is accompanied by a like impact of its policy preferences.
\end{abstract}

Keywords: global governance, multilateralism, realism, United Nations, United States.

\section{China and Global Governance}

The rise of China poses many challenges and opportunities for China as well as for other countries. One of the challenges, so far as international relations are concerned, is whether or not China will pose a threat to the existing world order. That is to say, whether or not China will change the way in which global affairs are being governed. At present, the governance of the existing system is dominated by such powerful states as the United States and those in Western Europe, in the sense that the extant international rules, which regulate the behaviour of states towards one another, are mostly made, interpreted, and enforced by these powerful states. Acting alone or in concert, they endeavour to protect and promote their national interests, very often in competition with other states but sometimes with each other. Apart from competition, they also sometimes cooperate among themselves or with others to tackle global problems. 
In ideological terms and in many other ways China is not part of the West. It is by and large a big developing country, although very different from most of the other countries in the Third World. It is huge in demographic size and in many aggregate measures, but remains relatively small in per capita terms. ${ }^{1}$ It is, however, a nuclear power with a veto in the United Nations Security Council. Will its rapid transition in development and its quick rise in various measures of power change the way in which the world is run? If so, in what way will global governance be affected? What are China's aspirations, demands, and limitations in its increasing engagement with global governance? This paper addresses these questions.

In political science governance refers to the regulation and management activities that aim at steering society to achieve some collective goals (Pierre and Peters 2000: 1). ${ }^{2}$ Drawing on the work of Robert Cox, the formation of global governance or governance without a world government can be seen as a transnational process of consensus formation among the major stakeholders of the global community that regulates and manages global issues effectively. Taking place through formal international organisations or informal forums, this multilateral, interactive process of consensus building generates consensual guidelines, rules and norms that are subsequently transmitted into the policy-making processes of states and non-state actors (Cox 1996: 296313). In other words, global governance is premised on the taking of collective and consensual actions by an array of actors, especially the more powerful ones, with the aim of regulating and tackling problems of global concerns in various issue-areas.

Here global governance refers simply to the various ways in which world affairs are being managed. The actors which exercise governance are many, including states and non-state actors such as interest groups, international organisations, and even individuals, although it is often acknowledged that powerful states, especially those in the West, are instrumental in shaping the way in which world affairs are run. ${ }^{3}$ These actors exercise their influence at many different levels, ranging from the individual and group levels to the state and global levels. The issues involved are numerous, including such important ones as trade, arms control, environmental protection, human rights, and so on. ${ }^{4}$ Seen in this light, global governance is an extremely complex matter. This is so in view of the accelerating pace of globalisation, which increases the speed, depth, and intensity of international connections. 
The process of globalisation, and hence global governance itself, is not something entirely new, but the momentum of change has increased significantly in contemporary times as a result of the ease of communications of various kinds, be they political, economic, social, or technological. In the case of China, the adoption of the reform and opening-up policy since 1978 has helped to speed up the process and complicate the substance of global governance. Many top Chinese leaders in the current fourth generation of leadership, including President $\mathrm{Hu}$ Jintao and Premier Wen Jiabo, have made numerous overseas trips around the world in recent years. Chinese businesspeople, sometimes travelling with their political leaders and diplomats, have been searching around the world for commercial opportunities and for oil and raw materials to fuel China's industrialisation. As a result of its breakneck industrialisation, it has been reported that China surpassed the United States in 2006 as the top emitter of carbon dioxide, a major component of greenhouse gases. ${ }^{5}$ Its industrial production led to its rapid rise in exports and investments. Initially its investment activities started inwards with the country becoming the largest recipient of FDI in 2002, but recently the country has turned outwards, focusing its investments on telecommunications, extracting industries, and other forms of capital expansion. ${ }^{6}$ Since the late 1970s, China has increased its participation in international organisations, ${ }^{7}$ both intergovernmental as well as nongovernmental ones. ${ }^{8}$ In line with such participation is the signature and ratification of major international treaties. ${ }^{9}$ All these involvements in world affairs are reflected in elite discourses of the country's engagement with global governance. A survey of a Chinese dataset called 'China Journal Net: Economics, Politics, and Law' reveals that the number of articles citing quanqiu zhili (global governance) was nil before 1994 and ranged from one to three before 1999, but rose sharply from over ten in 2000 to over sixty in 2006 (see Figure). ${ }^{10}$

To examine this interesting yet puzzling phenomenon of China's engagement with global governance, this paper proposes to examine China's view of the nature of global governance, and then to identify the principles and tactics used by the Chinese government in dealing with global governance before making an assessment of the features in this area of Chinese international relations. The paper turns next to the perceptions of other major countries towards China's behaviour in this area. The conclusion draws together the findings to make some observations. 
FIGURE 1 Citations of Global Governance in Journal Articles in China, 1979-2006

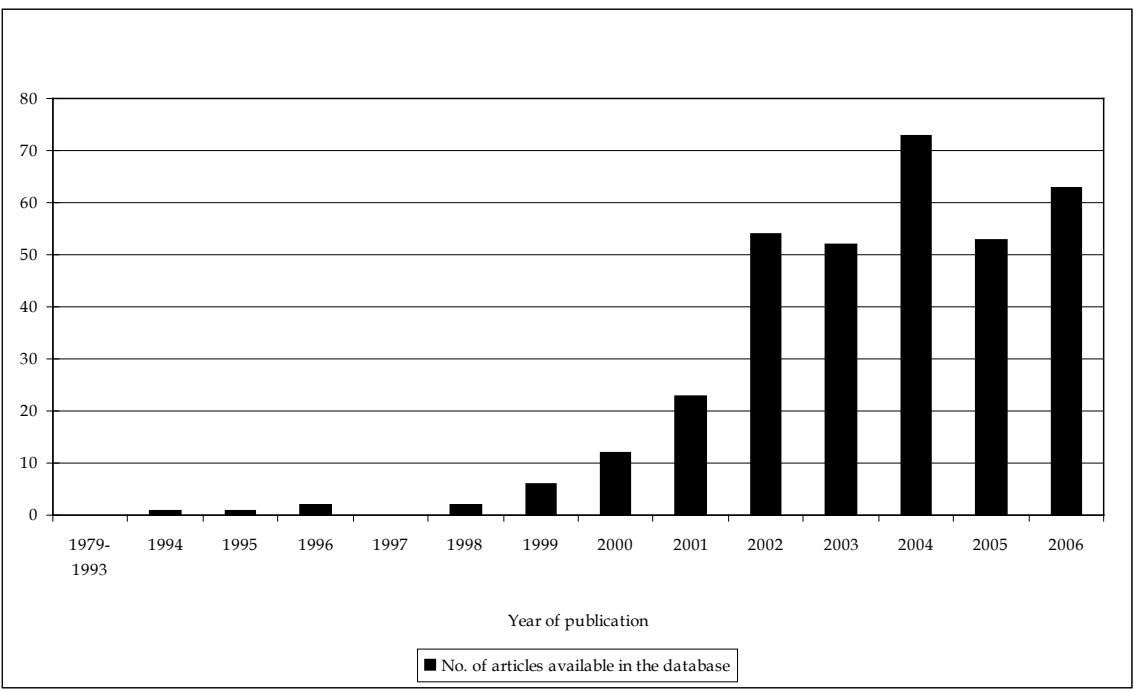

\section{China's View of the Nature of Global Governance}

China sees the existing structure of the international system and the nature of its governance as unequal, undemocratic, and therefore unjust. It is unequal because the distribution of global wealth is highly uneven, with the world's rich getting richer and its poor poorer. It is undemocratic because the world's imperialist hegemonies continue to ride roughshod over the weak, imposing their will and values on others without paying due attention to their plight and local conditions. Most decisions affecting major international relations are not made in accordance with the democratic principle of 'one state, one vote,' like the situation in the United Nations General Assembly. Rather they are made by the world's rich and powerful nations, particularly those in the West, and then imposed on the world as a whole. Because of this inequality and undemocratic way, the current state of global governance is therefore unjust. The message embedded in this line of thinking is that this system of governance, dominated by the West in general, and the U.S. in particular, needs to be changed. During the Maoist days, this intended change was to be brought about by revolutions. Now that the world situation is seen to be very different from that of the past in the Chinese eyes, change should instead be brought about by diplomatic means, typified by the use of carefully crafted principles and tactics. 


\section{The Principles of China's Global Governance}

The first principle of China's engagement with global governance is the pursuit of national interest. Here China is no different from most, if not all, other countries, irrespective of the different political systems that they choose to adopt. Neither is the second principle of the preservation of sovereignty different in any great measure from those of other countries. The differences in emphasis, if any, lie in the different capabilities, potential or perceived, that different countries command to protect and preserve their own sovereignty. A militarily and economically strong country like the United States does not have to worry too much about possible foreign infringements of its sovereignty because of its massive capabilities to retaliate. ${ }^{11}$ In comparison, China has to worry more about protecting its sovereignty. Firstly, there is the issue of Taiwan; a territory which has not yet been reunited with China despite the latter's effort to cut off Taiwan's international links and diplomatic relations with other countries and despite China's offer of commercial and political concessions of one kind or another to Taiwan. Strategically Taiwan can easily be exploited by other countries, for example the U.S., to pose a security threat to China. Apart from Taiwan, there is the problem of Tibet and other secessionist forces in Xinjiang province. The riots and demonstrations in Lhasa and other nearby places in March 2008 only serve to reinforce in the minds of China's leaders, that the Tibetan issue is a separatist issue of national sovereignty rather than an issue of human rights or ethnic difference. Secondly, China is still a relatively poor developing country. Although some of its coastal regions enjoy phenomenal economic growth and wealth, large parts of China still struggle to combat poverty, underdevelopment, and environmental problems. Thirdly, it has a recent history of being bullied by Western powers in the so-called one hundred years of national humiliation. It is still a fragile state in many respects (Shirk 2007). Fourthly, China shares its land borders with fifteen countries, and fourteen rivers with its neighbours. What China does or does not do to deal with territorial disputes and environmental pollution can easily affect neighbouring countries thereby cause potential conflicts. Thus China has to stand firm when dealing with issues of sovereignty and national interest. However, China also realises that it can hardly confront the United States head-on in military, political, or economic affairs. It has to play smart in handling its relations with the world's sole superpower so that China can properly protect and promote its national interests. To work cordially with the United States is seen to 
be the best option for China, although in doing so it has to endure occasional setbacks and short changes such as the loss of its Third World credentials. Meanwhile, it works unceasingly to build up a multilateral structure or a multipolar system in the world so as to check and balance the unilateral actions taken by the United States. ${ }^{12}$

\section{China's Strategies and Tactics in Global Governance}

Guided by the above principles, the Chinese government engages in global governance within the context of its overall foreign policy objectives. Discarding Mao Zedong's revolutionary zeal, Chinese foreign policy since the late 1970s when Deng Xiaoping came to power has become more pragmatic both in the goals to be achieved and the methods with which to achieve them. The 'three worlds' theory has given way to an independent foreign policy and then to peace and development, evolving into something that is multi-level, multi-faceted and omni- directional, aimed at winning friends from all over the world. This policy path anchors on the United Nations system as its bedrock, on which China builds its multilateral diplomacy. China believes that multilateral diplomacy enhances its block support from the Third World in its bargaining and negotiations with the West. A good example is China's siding with the developing world led by India and Brazil in the WTO Doha Round in negotiating the issue of agricultural subsidies handed out by governments in the rich developed countries to their own farmers (The Financial Times 2006). China sided too with the developing world in the Bali conference in December 2007 to discuss ways to tackle climate change when the Kyoto Protocol expires in 2012 (BBC News 2006).

Another evidence of China's pragmatic approach is its adoption of a win-win strategy, which aims to achieve mutual benefits rather than a one-sided gain based on self interest or ideological preference. This winwin strategic may run into difficulties with the West in some instances. China's involvement in Darfur, western Sudan, is a case in point. Governments in the West have heavily criticised China for turning a blind eye to human-rights abuses there in its pursuit of commercial interests and its search for oil. ${ }^{13}$ In response China says that it has no business to interfere in the internal affairs of other countries, ${ }^{14}$ a policy that stands in contrast to the idea of the 'responsibility to protect ${ }^{15}$ promoted by some countries in the West. This idea argues that the international community should intervene to provide the necessary protection to local residents if governments fail to do so or if these governments commit genocide, war 
crimes, ethnic cleansing, or crimes against humanity. African countries receiving Chinese aid or enjoying substantial trade with China are of two minds: some welcome China's involvement, which provides an alternative source of help and an alternative model of development in view of Western failures to reduce Third World poverty in the past decades; others may feel that China is no different from other colonial masters in the past who tried to exploit their resources (Thompson 2007). As a way to lessen the concerns of the West over China's aid policy towards Africa, the country has agreed to join forces with the World Bank to coordinate aid to African countries so as to help them achieve sustainable development in an open and transparent way (Wheatley 2007).

In the pursuit of a pragmatic strategy in international affairs, China exhibits behaviour in two notable areas. One is the joining of international organisations and the entering into international treaties, thereby bringing China's standard of behaviour closer to international standards through complying with global norms and rules. The record of China's global compliance is, however, a mixed bag, given the fact that China is still relatively new to the international system, a system which has been dominated by the West since its modern inception. Also, in many areas, China lacks the capacity if not the will to comply. For example, China lacks a robust legal system and there is a mismatch between the central and local governments in policy implementation. Nevertheless, China is now a full member of the international community, by membership count if not by active participation in the full range of activities of international organisations. For the foreseeable a gap is likely to remain between China's actual practice and the standard of behaviour expected of it by the West although this gap has been narrowing over time since the 1980s despite occasional setbacks. ${ }^{16}$

Another kind of behaviour that China exhibits in the pursuit of a pragmatic strategy is the exercise of soft power. This is done deliberately as well as by coincidence as China tries to develop and modernise, hopefully within a stable international environment and a congenial domestic situation. China does not seem to have a grand design to pursue big-power politics by flexing its military muscles in the pursuit of its national interests. Rather it tries to promote trade and investments and to make its presence felt through tourism, social, cultural, and educational exchanges. The establishment of some 200 Confucius Institutes around the world to promote Chinese language and culture has been cited by many observers as an example of China's exercise of soft power. It is difficult to assess the extent to which China is successful in projecting its 
soft power. Different scholars seem to make different assessments, but most would agree that China's spread of its soft power is underpinned by its increasing economic and military might. In terms of its political system and institutions, the country offers little to emulate. ${ }^{17}$ Its overall politico-economic development, however, does provide some hope and possibly some useful guides for many Third World countries to consider in their political transition and economic development.

\section{Characteristics of China's Global Governance}

From the above analysis, it becomes clear that the main characteristic of China's global governance is its realpolitik position in dealing with world affairs. This realpolitik approach is buttressed by realism based on the enhancement of national interest and the protection of sovereignty, a kind of classical embodiment of realist politics, coupled with pragmatism in handling current problems that the country faces and in fulfilling its aspirations. ${ }^{18}$ If China's realism is little different to other types of realism pursued by other countries, then perhaps China's sense of realism is more urgently felt and is more solidly embedded in its traditions and in its modern encounter with imperialism. It is shaped by its rather unique experience of being a large country with a long history that had been largely closed to the outside world for some 600 years before the mid-nineteenth century. China's realism is heavily led by the state, more so perhaps than in many other countries, but it shows increasing adaptability and flexibility in contemporary times.

Despite China's increasing involvement in world affairs and global governance, its international profile is still largely a low-key one. This Chinese style can partly be explained by its long tradition of being a conservative and inward-looking civilisation, and partly by its lack of international experience, given the fact that it was very reluctantly dragged into the world system, a system it had been trying unsuccessfully to shun since the mid-nineteenth century. Although a small group of intellectuals may have been willing to learn from the outside, the country's tradition and conservatism have acted as a brake from time to time in the long process of global social learning. In the transition from tradition to modernity, China has shown traits of both old and new, rigidity and flexibility, die-hard habits and modern adaptations. This situation begs the question as to whether China is really internationalising and being socialised into international norms or whether it is trying to adjust tactically in order to advance its interests under dif- 
ficult circumstances which it wants to avoid as far as possible. ${ }^{19}$ China's socialisation experience with the practice outside is less than clear-cut; much depends on circumstances, the issues involved, and timing. It is fair to say that there is a lot of fluidity, a kind of a mix or an uneasy harmony of yins and yangs. ${ }^{20}$ In a certain sense, China tries to harmonise itself with outside demands, whether they come from other states or international organisations or out of its own realisation of the need to do so. Certainly, China is changing to look more like a 'normal' state, more akin to the standard practices in the outside world, in a competitive game of global politics. An important question that follows on from this development is how other countries perceive China's changing engagement with global governance.

\section{How Do Others View China's Global Governance?}

Four views are briefly considered here: that of the European Union, the United States, Asian countries, and the developing world. It is difficult to assess the views of a group as large and as diverse as the twenty-seven member states of the EU, given the fact that some of them may have different ideas as to how to deal with China's human-rights behaviour, the issue of trade protectionism, the issue of strategic and military ties, and others. It is fair to say that on the whole the EU is more accommodating to China than the United States. ${ }^{21}$ Although major countries such as France and Germany, not to mention the U.K., have more in common with the U.S. than with China in terms of culture, tradition, and strategic outlook, they also want to have a stable international environment sustained by a balance of power, through their own experiences in the European theatre. This particular line of thinking ties in well with China's: to see to it that U.S. unilateralism can be checked in order to attain global stability underpinned by different power centres each balancing the other in alliances and partnerships, formal or informal. The rise of China in trade and finance adds a new factor for EU countries to consider when they develop their relations with China, as China offers both challenges and opportunities that EU countries can ill afford to ignore. The EU can play a balancing act between China and the U.S. The exact configuration of this balance depends on the particular issues and actors involved, the kind of the bilateral relationships in question, and the personal chemistry between leaders, among other factors.

Sino-U.S. ties have been marked by a love-hate relationship for a long time, and the present U.S. policy towards China consists of a mix 
of containment and engagement, or 'congagement', as a Rand Corporation analyst in California has put it. ${ }^{22}$ While some hawkish elements in the country favour a policy of containment, trying to limit China's influence, there are elements within the U.S. political establishment which call for an active engagement with China, since a rising China is largely benign and inevitable. These two policy lines - containment and engagement - can hardly be separated from each other. They exist with each other most of the time, even if official statements in the U.S. stress the importance of one over the other at different times and under different sets of circumstances. Despite their differences over human-rights issues, the status of Taiwan, trade, environmental protection, nuclear non-proliferation, and other areas, bilateral contacts at various levels have increased recently. The latest contacts include the establishment in 2006 of the Strategic Economic Dialogue which brings together trade ministers to exchange views and to discuss issues of mutual concerns beyond the purview of trade and economics.

The presence of American military, economic and political influence in Asia plays an important part in shaping the perceptions of China harboured by Asian countries. Most of these countries are dwarfed by China's size, and traditionally they have come under the influence of the Chinese Empire. They fear the dominance of China and yet they have to find a way to live and work with this giant neighbour. The presence of the U.S. in the region helps to ease somewhat Asian fears of China. Asian countries jump readily onto the American bandwagon in dealing with China. Their fear of a militarily strong China is only mitigated by the U.S. presence in Asia and America's bilateral and multilateral military relations with many of them. The initial fear of China as an economic power which could take away the markets of many Asian countries and divert investment flows away from them have proved to be exaggerated. In reality China has become the engine of growth for Asia, providing a ready market for Asian products and a low-cost manufacturing centre for some Asian countries. China's attraction of FDI has not been at the expense of other Asian countries, as previously thought to be the case. As a result, many Asian countries now look towards China as a major opportunity. Whether or not they fear a militarily strong China has largely been left unsaid among Southeast Asian politicians. Also there are unresolved disputes between China and its neighbours such as the territorial disputes in the South China Sea and the East China Sea. In a survey of 'how the world sees China' released by Pew Research Center in late 2007, apart from Japan and India, nearly all Asian countries hold 
a favourable view of China's rise in the world (see pewresearch.org site 2007). This cannot be said, however, of the public opinions of the West towards China, whose popularity rating has been plummeting because of China's poor human-rights record, the low safety standard of Chinese products, and the taking away of jobs in the industrialised West by China.

Although China is not a member of the Non-Aligned Movement, nor is it an active member of the Group of 88, China claims to be a developing country belonging to the Third World. In official pronouncements and in actual behaviour, China does seem to curry favour with Third World countries, giving an increasing amount of trade concessions and assistance of various kinds to an increasing number of them. The fact that China has managed to generate phenomenal economic growth has presented an attractive model for other developing countries to adopt. The lure of China's soft power in the developing world, especially in Africa, has caused considerable alarm in the West. ${ }^{23}$ The successful holding of the China-African summit in Beijing in November 2006 led to the catching up of the EU-African summit in Lisbon in December 2007. The lukewarm and uneven reception of the economic partnership agreements proposed by the EU serves to show Africa's increased leverage because of its newly established China connection (BBC News 2007). Whether China has provided a model of development - strong economic growth coupled with strong authoritarian rule - for other Third World countries to follow is too early to say. At least China has provided an alternative way to modernisation and an alternative source of foreign aid with little or no conditions attached. ${ }^{24}$

\section{Conclusion}

One of the most intriguing questions surrounding China's current involvement in global governance is whether the country is a peaceful power in the international community or a rising challenger to the existing order. From the foregoing analysis, it is quite clear that China's rise embodies elements of both, but perhaps with a difference in prominence. There is no doubt in the minds of most observers that China is rising in aggregate powers, although some may dispute whether this is a rise or a revival. In any case, China wants to stand tall in the sense of trying to get rich and powerful quickly, a revival of its former glory long before the arrival of imperialism on its shore. To do this, China wants to have a stable and peaceful environment so that it can develop 
smoothly. However, doubt has been expressed as to whether, if and when China has eventually become rich and powerful, it will behave like other rising powers before it, that is, will China become a hegemony with imperialist behaviour? No one quite knows the answer; different people, looking at the same situation from different angles, may have come to different conclusions.

In official statements, the U.S. would like to see China as a responsible stakeholder in world affairs. ${ }^{25}$ By acknowledging that China as a stakeholder, the U.S. recognises the status and certain rights of China in the international system. This American recognition seems to have pleased the Chinese, as the Chinese government has fought to be properly recognised and respected for much of the past century and a half. ${ }^{26}$

The U.S. wants to see China as a responsible member of the international community, in which China will comply with the existing rules and norms that are designed and maintained by the West, and the U.S. in particular. China, on the other hand, would like to be seen as a responsible member, partly out of its desire to maintain a good public image and partly because it does not want to antagonise the West unnecessarily. However, it realises that the existing system is not always working in its favour, or that the same system does not distribute a fair share of costs and benefits to the developing world. Therefore China aspires to work, wherever possible within limits, to change the existing rules so that they can set a fairer way of treating China and other developing countries. In this respect, China wants to be a co-architect of some sort with the U.S. in revising the existing system of rules, although it is very likely to begin as a junior partner in this endeavour. Other major powers in the Group of Eight industrialised countries will inevitably be involved in this global restructuring. Whether or not the U.S. will allow such a revision of the global-governance architecture to take place or to what extent the U.S. will allow China to have a greater say in world affairs remain to be seen. The interaction between the U.S. and China in global governance is likely to determine to a reasonably large extent the shape of the world to come, so that we might see this complex development as global governance with some Chinese characteristics!

Dr Gerald Chan is Professor of Political Studies, Department of Political Studies, University of Auckland, New Zealand. 


\section{ACKNOWLEDGEMENTS}

I am grateful to two anonymous reviewers of the Copenhagen Journal of Asian Studies for their comments and criticisms on an early version of this paper. I also wish to thank Lai-Ha Chan and Pak K. Lee for borrowing a few ideas from our joint paper entitled 'Rethinking global governance: A China model in the making?' Contemporary Politics, Vol. 14, No. 1 (March 2008), pp. 3-19. An earlier, shorter version of this paper was published in an in-house journal Politika, Politics and Public Administration Association, University of Hong Kong, 2007, pp. 7-14.

\section{NOTES}

1 For example, in per capita GDP, in per capita use of resources such as oil, minerals, and water, and even in per capita emission of greenhouse gases.

2 The idea of this paragraph owes a lot to Pak K. Lee of the University of Kent, UK.

3 A recently published book reinforces the important role played by states in global regulations, despite the rise of non-state actors in an era of globalisation and interdependence (see Drezner 2007).

4 For a wide array of world problems that the humankind faces, see Yearbook of International Organizations, 2006 volume 4.

5 According to the Netherlands Environmental Assessment Agency, China led the world in carbon dioxide emissions in 2006 by producing 6.2 billion tonnes of the gas. The U.S. churned out 5.8 billion tonnes. The rise was due to China's dependence on coal as its major energy source as well as its rising production of cement (Vidal and Adam 2007).

6 China has accumulated the world's largest national foreign exchange reserve, over US\$1 trillion as of 2007. It is looking outwards to invest its sovereign wealth fund. For an analysis of a shift in global financial change in this respect, see The Times 2007: 56-7.

7 For an up-to-date and extensive study of China and international organisations, see Kent 2007.

8 As of 2005 China was a member of 203 intergovernmental organisations and 4,416 international non-governmental organisations. These figures include five types of international organisations: federation of international organisations; universal membership organisations; intercontinental membership organisations; regionally oriented membership organisations; and organisations of special form. See Yearbook of International Organizations, 2006: 56 (Volume 5).

9 As of 2006 China has acceded to 302 multilateral treaties, the majority of which have been signed after 1979, amounting to 88 percent of all treaties that China has signed after its establishment in 1949 (see China's Ministry of Foreign Affairs website and Chan 2006: 70-75).

10 Despite the increasing academic attention paid to global governance, Pang Zhongying laments the lack of significant contributions to the theoretical and empirical studies of global governance from Chinese scholars (see Pang 2006: 60-2).

11 This might explain in part why the West favours the concept of 'responsibility to protect', a concept that suggests that the international community should intervene should governments fail to protect its own citizens from widespread abuse of human rights, while China (and others) is fiercely against it.

12 China's multilateral diplomacy has recently been analysed by $\mathrm{Wu}$ and Lansdowne (eds) 2008. 
13 The amount of oil that China gets from Sudan is relatively small compared with what it gets from other countries in Africa and the Middle East, so that the argument that China is in Darfur purely for the sake of oil does not stand to scrutiny because of the heavy damage done to its international reputation.

14 China of course has softened it stance by appointing a special envoy to deal with the situation in Darfur and in agreeing to the deployment of a combined UN/African peacekeeping force. In November 2007 a vanguard of 135 Chinese engineers arrived in Darfur to start peacekeeping duties (see Xinhua News 2007). In early 2008 the number of Chinese engineers is Darfur had increased to around 300.

15 For an elaboration of the concept of 'responsibility to protect', check the website of the International Crisis Group.

16 For a detailed analysis over several case studies, see Chan 2006 and Kent 2007.

17 Sheng Lijun, expressing his views on China's soft powers, in an international conference on China, organized by the China Institute of the University of Nottingham, in September 2006.

18 For a sustained analysis of China's pragmatism in its foreign policy, see Zhao (ed) 2004.

19 Alastair Iain Johnston has done a substantial amount of work in addressing this question, see his latest book (2008).

20 To go beyond this simple dialectic situation to explore theoretically four possible options for a country, including China, to respond to international regulatory regimes, see Drezner 2007. To paraphrase, these four options are: to harmonise oneself with international norms; to form a rival group to oppose those norms; to join the existing club of powerful states that design and reinforce those norms; or to strategically adapt to or sham those standards (see especially Drezner 2007: 71-88).

21 There are exceptions, however. For example, the US takes a somewhat different path from some of its major European allies in dealing with China's policy towards Tibet. Instead of announcing a boycott of the opening ceremony of the Beijing Olympic Games in August 2008, it prefers to engage with China and to apply subtle pressure on China to change it rather than to confront it directly.

22 The term 'congagement' was coined by Khalilzad et al. 1999: 72.

23 For a recent book-length discussion on China's soft power, see Kurlantzick 2007. See also Gill and Huang 2006; Wang 2008.

24 For a development of this idea, see Chan, Lee and Chan 2008.

25 The term 'responsible stakeholder' was reportedly first coined by Robert Zoellick in September 2005 when he was the U.S. Deputy Secretary of State. Since mid-2007 he has joined the World Bank as its president. See Zoellick's article at state.gov site (accessed 3 January 2008).

26 The same concept of stakeholder had been repeatedly used by Robert Zoellick, in his capacity as President of the World Bank, when he successfully invited in December 2007 China's Import-Export Bank to contribute financial help to the World Bank's International Development Association to help Africa (see Wheatley 2007).

\section{REFERENCES}

Bates, G. and Huang Yanzhong 2006. 'Sources and limits of Chinese "soft power"'. Survival 48 (2): 17-36.

BBC News 2006. 'US sets terms for climate change', 15 December.

BBC News 2007. 'EU host hails "summit of equals"', 8 December. 
Chan, G. 2006. China's Compliance in Global Affairs: Trade, Arms Control, Environmental Protection, Human Rights. Singapore: World Scientific.

Chan, Lai-Ha, Pak K. Lee and G. Chan 2008. 'Rethinking Global Governance: A China Model in the Making?' Contemporary Politics 14 (1), March, pp. 3-19.

Cox, R. W. 1996. 'Global perestroika'. In Robert W. Cox with Timothy J. Sinclair (eds). Approaches to the World Order. Cambridge: Cambridge University Press: 296-313.

Drezner, D. W. 2007. All Politics is Global: Explaining International Regulatory Regimes. Princeton and Oxford: Princeton University Press.

http:// pewresearch.org/pubs/656/how-the-world-sees-china [accessed 17 December 2007].

International Crisis Group. www.crisisgroup.org.

Johnston, A. I. 2008. Social States: China in International Institutions, 1980-2000. Princeton and Oxford: Princeton University Press.

Kent, A. 2007. Beyond Compliance: China, International Organizations, and Global Security. Stanford: Stanford University Press.

Khalilzad, Z. M. et al. 1999. The United States and a Rising China: Strategic and Military Implications. Santa Monica, CA: Rand Corporation.

Kurlantzick, J. 2007. Charm Offensive: How China's Soft Power Is Transforming the World. New Haven and London: Yale University Press.

Ministry of Foreign Affairs, China, www.fmprc.gov.cn/chn/wjb/zzjg/tyfls/tfsckzlk/ zgcjddbty/default.htm [accessed 10 September 2007].

Pang Zhongying 2006. 'Guanyu Zhongguo de Quanqiu Zhili Yanjiu [On the study of global governance in China]'. Xiandai guoji guanxi [Contemporary international relations]. Beijing, No. 3.

Pierre, J. and B. G. Peters 2000. Governance, politics and the state. Basingstoke: Macmillan.

Shirk, S. L. 2007. China: Fragile Superpower: How China's Internal Politics Could Derail Its Peaceful Rise. Oxford: Oxford University Press.

Thompson, J-P 2007. 'China's Crucial Role in Africa - Vol. 6: China in Africa'. August-November. Available from www.africafiles.org/atissueezine.asp [accessed 4 January 2008]

The Financial Times 2006. 'US blamed as trade talks end in acrimony', 24 July.

The Times, 22 December 2007.

Vidal, J. and D. Adam 2007. 'China Overtakes US as World's Biggest CO2 Emitter'. The Guardian, 19 June.

Wang, Y. 2008. 'Public Diplomacy and the Rise of Chinese Soft Power'. The Annals of the American Academy of Political and Social Science, No. 616, March, pp. 257-273.

Wheatley, A. 2007. 'World Bank Eyes Joint Africa Projects with China,' Reuters, 18 December.

Wu, G. and H. Lansdowne (eds) 2008. China Turns to Multilateralism: Foreign Policy and Regional Security. London and New York: Routledge.

Xinhua News 2007. www.chinaview.cn. 24 November.

Yearbook of International Organizations 2006-2007. München: K.G. Saur, 2006.

Zhao, S. (ed) 2004. Chinese Foreign Policy: Pragmatism and Strategic Behavior. Armonk, NY and London: M.E. Sharpe.

Zoellick, R.. 'Whither China: from membership to responsibility?' www.state.gov/s/ d/former/zoellick/rem/53682.htm [accessed 3 January 2008]. 